\title{
Detection of Turkey Rhinotracheitis Virus from Chickens with Swollen Head Syndrome by Reverse Transcriptase-Polymerase Chain Reaction (RT-PCR)
}

\author{
Masaji MASE, Setsuo ASAHI ${ }^{1}$, Kunitoshi IMAI, Kikuyasu NAKAMURA, and Shigeo YAMAGUCHI \\ National Institute of Animal Health, 3-1-1 Kannondai, Tsukuba, Ibaraki 305 and ${ }^{1}$ Chusei Livestock Hygiene Service \\ Center of Mie Prefecture, 3841-4 Takajayakomoricho, Tsu, Mie 514, Japan \\ (Received 11 August 1995/Accepted 21 November 1995)
}

ABSTRACT. We developed a sensitive and specific method, reverse transcriptase-polymerase chain reaction (RT-PCR) method, for detection of turkey rhinotracheitis virus (TRTV). Two sets of primers were designed from F protein gene sequence of TRTV 3B strain. Sensitivity of detection by nested PCR with the primers corresponded to $0.4 \mathrm{TCID}_{50}$. Applying this method to a field case of swollen head syndrome (SHS), TRTV could be detected directly from chicken trachea and turbinates. It was identified that this method was very useful to examine the relation of TRTV and SHS. - KEY wORDS: RT-PCR, SHS, TRTV.

J. Vet. Med. Sci. 58(4): 359-361, 1996

Swollen head syndrome (SHS) of chickens was first described in South Africa in 1984 [7]. Mixed infection with viruses and bacteria was suspected to cause the syndrome [7], but the causative factors have not been clearly identified yet. In Japan, SHS was first described in Hyogo prefecture in 1989 [13]. Thereafter, the syndrome has been reported all over Japan. The syndrome has seen mainly in broiler chicken flocks, and it was characterized by subcutaneous edema of the head. The edema may be mainly caused by bacteria, but some other factors may be necessary to induce bacterial infection. Many reports described a rise in antibodies to turkey rhinotracheitis virus (TRTV) in serum samples of chickens with SHS $[1,9,14]$. So, TRTV is considered as a primary predisposing viral factor triggering SHS. To elucidate the role of TRTV infection for SHS outbreaks, virus isolation and characterization of the isolate is neccesary. However, isolation of TRTV from chickens with SHS has succeeded only in a few cases $[3-6,10]$. Because TRTV is a fastidious virus, and it is difficult to isolate the virus in general avian virus isolation techniques using chicken kidney cell, chicken embryo fibroblast or embryonating eggs. And also, antibody to TRTV turned to be positive in most of the cases when chickens showed clinical signs of SHS. Recently, reverse transcriptase polymerase chain reaction (RT-PCR) method is applied to rapid diagnosis of many virus infections. In this study, we developed a sensitive and specific method, RT-nested PCR method, for detection of TRTV directly from chickens with SHS to conquer difficulty of virus isolation.

For the RT-nested PCR, we designed two sets of oligonucleotide primers consisted of a sequence identical to a region of $F$ protein gene of TRTV 3B strain [12]. The primer set of F1 (GATCAAGTGGCTAAGGAAAG) and F3 (CCATCATAAACACCAATCAA) was for the 1st PCR, and F2 (ATTAGAGGGAGAGGTGAAGG) and F5 (ACATCAAACTAATCTGTCCT) was for the 2nd PCR (nested PCR). Predicted size of the 1st PCR product was $536 \mathrm{bp}$, and the nested was $347 \mathrm{bp}$. The amplifying DNAs were designed to contain restriction enzyme site of $P s t \mathrm{I}$. For cDNA synthesis by RT, $1 \mu l$ of the RNA solution was mixed with $2 \mu l$ of $10 \times$ reverse transcriptase buffer (100
$\mathrm{mM}$ Tris- $\mathrm{HCl}, 500 \mathrm{mM} \mathrm{KCl}, \mathrm{pH} 8.3), 4 \mu l$ of $25 \mathrm{mM} \mathrm{MgCl}_{2}$, $2 \mu l$ of $2.5 \mathrm{mM}$ each of deoxyribonucleotide triphosphates (dATP, dGTP, dCTP and dTTP), 20 units of RNase inhibitor, $1 \mu l$ of $50 \mu \mathrm{M}$ random 9 mer oligonucleotide, 5 units of avian myeloblastosis virus reverse transcriptase. A $20 \mu l$ total reaction volume was obtained by adding diethylpyrocarbonate (DEP) treated water. Reaction solution was incubated for $10 \mathrm{~min}$ at $30^{\circ} \mathrm{C}$ and for $30 \mathrm{~min}$ at $42^{\circ} \mathrm{C}$. After incubation, the reaction was stopped by heating to $95^{\circ} \mathrm{C}$ for $5 \mathrm{~min}$. For the $1 \mathrm{st}$ PCR, $5 \mu \mathrm{l}$ of cDNA solution described above were mixed with $2 \mu l$ of $10 \times$ PCR buffer $(100 \mathrm{mM}$ Tris- $\mathrm{HCl}, 500 \mathrm{mM} \mathrm{KCl}, \mathrm{pH} 8.3$ ), $3 \mu l$ of $25 \mathrm{mM} \mathrm{MgCl}_{2}$, $0.25 \mu l$ of $20 \mu \mathrm{M}$ of each primer, and 2.5 units of Taq DNA polymerase. A $25-\mu l$ total reaction volume was obtained by adding sterile distilled water. For the nested PCR, 0.25 $\mu l$ of 1 st PCR products were mixed with $2.5 \mu l$ of $10 \times$ PCR buffer (100 mM Tris- $\mathrm{HCl}, 500 \mathrm{mM} \mathrm{KCl}, 15 \mathrm{mM} \mathrm{MgCl}$, $\mathrm{pH} 8.3$ ), $2 \mu l$ of $2.5 \mathrm{mM}$ each dNTP, $0.25 \mu l$ of $20 \mu \mathrm{M}$ of each primer, and 2.5 units of Taq DNA polymerase. A 25$\mu l$ total reaction volume was obtained by adding sterile distilled water. Both of the 1 st and 2 nd PCR were performed by 30 cycles of $94^{\circ} \mathrm{C}$ for $1 \mathrm{~min}, 55^{\circ} \mathrm{C}$ for $1 \mathrm{~min}$, and $72{ }^{\circ} \mathrm{C}$ for $2 \mathrm{~min}$.

The 14/1 strain of TRTV isolated from turkey [14], was firstly used for standardization of the RT-nested PCR method. Viral RNA was extracted by sodium dodecyl sulfate (SDS)-phenol method. Briefly, SDS [final concentration $1 \%(\mathrm{w} / \mathrm{v})$ ] was added to viral sample, and RNA was extracted with phenol/chloroform/isoamyl-alcohol (25:24:1). Then, the RNA was resuspended in DEP treated water. Suitability of the RT-nested PCR reaction for amplification of TRTV genome was confirmed by production of predicted size of DNA and existence of $P_{s t I}$ site in the amplified DNA (Fig. 1).

For the specificity test, the following viruses were examined: Newcastle disease virus; B1 strain, avian influenza virus; A/budgerigar/Aichi/1/77 (H3N8) strain, infectious bronchitis virus; Be 42 strain, avian reovirus; Uchida strain, and bovine respiratory syncytial virus (bovine pnuemovirus); NMK strain. Amplified DNAs were not detected from any samples except TRTV (date not shown). 


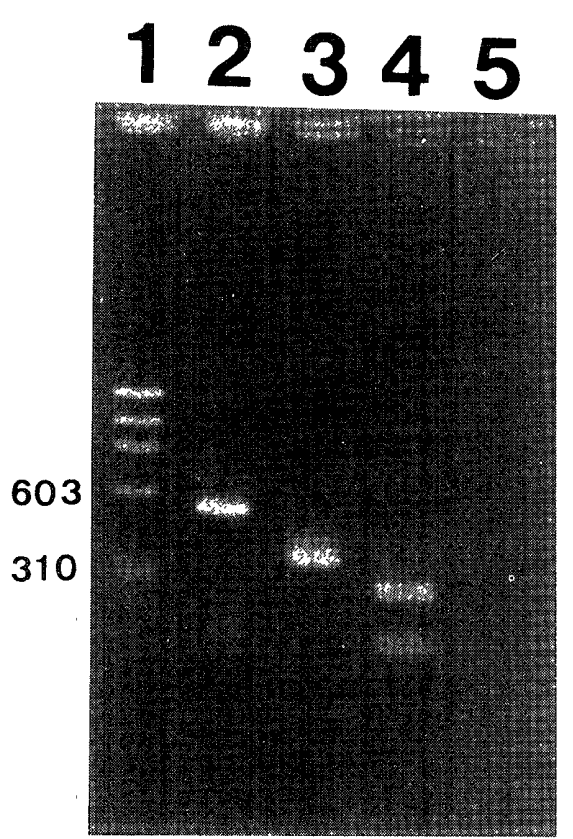

Fig. 1. Detection of TRTV from tissue culture fluid of infected CEF cells. Lane 1: Size marker ; Lane 2: 1st PCR products by primer set of F1 and F3; Lane 3: Nested PCR products by primer set of $\mathrm{F} 2$ and $F 5$; Lane 4: Nested PCR products digested by restriction enzyme PstI. Lane 5: Nested PCR with non-infected CEF cells.

Next, the sensitivity of the RT-nested PCR were examined. Sensitivity of detection by the 1st PCR corresponded to $10^{1.6} \mathrm{TCID}_{50}$ and the nested corresponds to $0.4 \mathrm{TCID}_{50}$ (Fig. 2).

Then, we applied this RT-nested PCR method to a field case of SHS. An outbreak of SHS occurred in a commercial broiler farm in Mie prefecture during the summer of 1994. The samples, such as trachea and turbinates were collected from chickens clinically diagnosed as SHS. RNA were extracted from the samples using a RNA isolation kit (ISOGEN, Nippongene). RT-nested PCR were performed as described above. As a result of examining 5 chickens, amplified DNAs were detected in 1/5 from tracheas and 4/5 from turbinates (Fig. 3). All of the amplified DNAs had a Pst $\mathrm{l}$ site (date not shown). For further confirmation of the PCR products, one of the amplified DNAs from tracheal samples was sequenced as below. The RT-nested PCR product was cloned into pCR II plasmid (TA cloning kit, Invitogen) and sequenced by dideoxynucleotide chain termination method using forward and reverse M13 sequencing primers. As the obtained sequence had a quite high homology (99.7\%) to the reference sequence of the 3B strain (Fig. 4), it was confirmed that the amplified DNA was derived from TRTV gene. The nucleotide sequence date reported in this paper resistered in DDBJ nucleotide sequence database with the accession number of D49957.

Virus isolation was tried with $20 \%$ tissue homogenate collected from the outbreak in Mie prefecture. These were
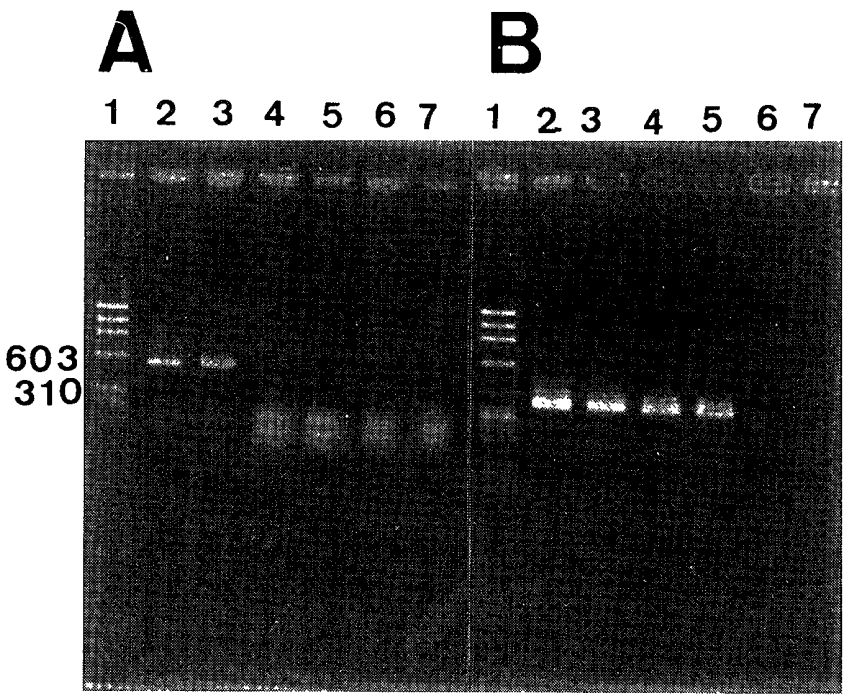

Fig. 2. Sensitivity of 1st PCR (A) and nested PCR (B) with serial dilution of TRTV. Lane 1: Size marker; Lane 2 to 7: Serial 10-fold dilution of TRTV $14 / 1$ strain from $10^{2.6} \mathrm{TCID}_{50}$.

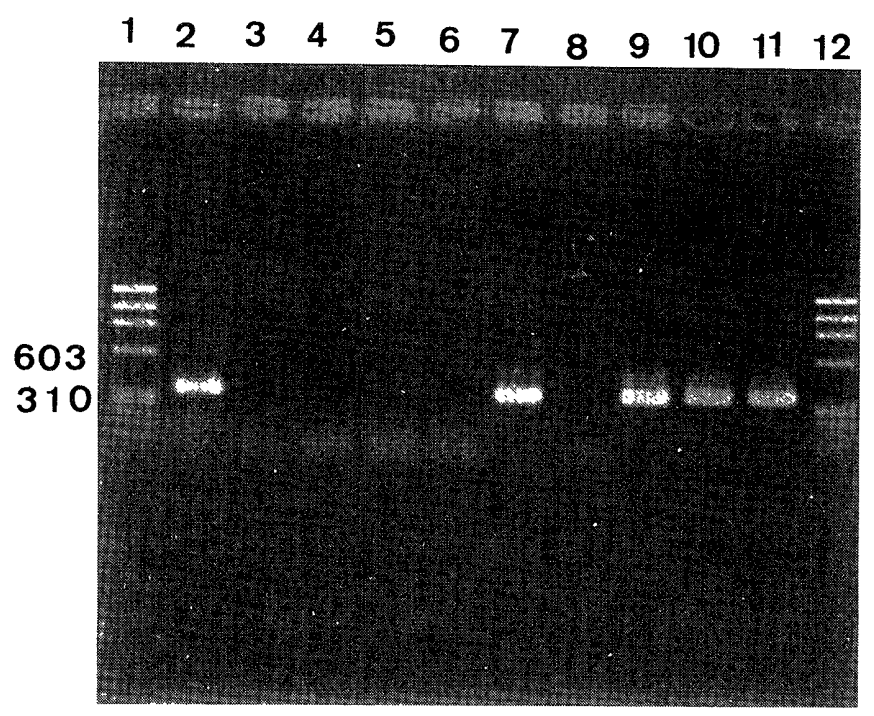

Fig. 3. Detection of TRTV from a field case of SHS in Mie prefecture. Lane 1 and 12: Size marker; Lane 2 to 6: Tracheal sample number 1 to 5 ; Lane 7 to 11: Turbinates sample number 1 to 5 .

same samples used for RT-PCR. The samples were filtered through a $450 \mathrm{~nm}$ membrane, and inoculated into chicken tracheal organ culture (TOC) of 20-day-old specific pathogen free (SPF) chicken embryonated eggs obtained from a White Leghorn flock maintained in our laboratory [2]. And also, these materials were inoculated to chicken kidney cell culture, chorioallantoic cavity of 10-day-old SPF chicken embryonated eggs and yolk sac of 6-day-old SPF chicken embryonated eggs. No virus was isolated from the samples in any inoculation method. However, preverance of TRTV in all of the chickens examined was detected by serum neutralization test with $14 / 1$ strain.

The results of the RT-nested PCR revealed sensitive and specific detection of TRTV directly from respiratory tract 


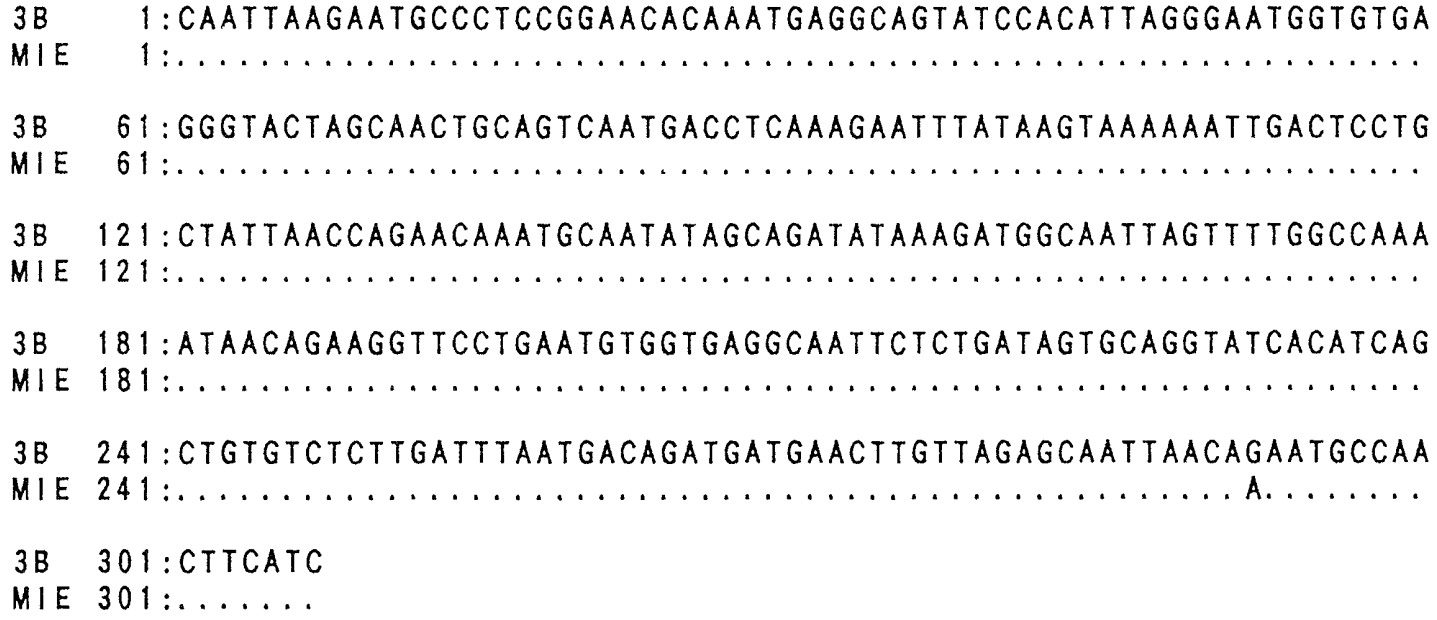

Fig. 4. Comparison of sequence between reference sequence of TRTV 3B strain and nested PCR product. Upper row is showing reference sequence of $3 \mathrm{~B}$ strain. Lower row is showing sequence of amplified region of a tracheal sample from a field case of SHS in Mie prefecture. Identical sequences to upper row are shown by dot.

of chickens. TRTV isolation with cell culture is very difficult and the most sensitive method is currently considered to be TOC of turkey or chick embryo [8]. Even with the TOC method, we could not isolate TRTV from chickens which were positive by the RT-nested PCR. Moreover, TOC inoculated with TRTV have to be observed for 7 to 10 days for detection of ciliostasis. In contrast, detection of TRTV by the RT-nested PCR was highly sensitive and time saving. It took less than 2 days to detect and identify the virus. A high homology of nucleotide sequence between TRTV isolated from a turkey in Europe and that detected from a chicken in Japan suggests that TRTV can easily transmit between turkey and chicken and the virus was introduced into Japan recently. Up to the present, reproduction of SHS by experimental inoculation of suspected agents has not succeeded yet. So, a role of TRTV in SHS is not identified. This PCR method would be useful to examine the relation TRTV and SHS.

\section{REFERENCES}

1. Cook, J. K. A., Dolby, C. A., Southee, D.J., and Mockett, A. P. A. 1988. Avian Pathol. 17: 403-410.

2. Furuta, K., Ohashi, H., Obana, J., and Sato, S. 1980. Lab. Anim. 14: 107-112.
3. Gough, R. E., Manvell, R. J., Drury, S. E. N., and Pearson, D. B. 1994. Vet. Rec. 134: 353-354.

4. Jones, R. C., Naylor, C. J., Bradbury, J. M., Savage, C. E., Worthington, K., and Williams, R. A. 1991. Vet. Rec. 129: 509-510.

5. Lu,Y. S., Shien,Y. S.,Tsai, H. J., Tseng. C. S., Lee. S. H., and Lin, D. F. 1994. Avian Pathol. 23: 169-174.

6. Maharaj, S. B., Thomson, D. K., and da Graca, J. V. 1994. Vet. Rec. 134: 525-526.

7. Morley, A. J. and Thomson, D. K. 1984. Avian Dis. 28: 238243.

8. Naylor, C. J. and Jones, R. C. 1993. Vet. Bull. 63: 439-449.

9. Obrien, J. D. P. 1985. Vet. Rec. 117: 619-620.

10. Pattison, M., Chettle, N., Randali. C. J., and Wyeth, P. J. 1989. Vet.Rec. 125: 229-231.

11. Picault, J. P., Giraud, P., Drouin,. P., Guittet, M., Bennejean, G., Lamande, J., Toquin, D., and Gueguen, C. 1987. Vet. Rec. 121: 135 .

12. Yu, Q., Davis, P. J., Barrett, T., Binns, M. M., Bourshnell, M. E. G., and Cavanagh, D. 1991. J. Gen. Virol. 72: 75-81.

13. Uramoto, K., Hakogi, E., Watanabe, T., Ogura, Y., Hataya, M., and Otsuki, K. 1990. J. Jpn. Soc. Poult. Dis. 26: 247-253 (in Japanese).

14. Wyeth, P. J., Gough, R. E., Chettle, N., and Eddy, R. 1986. Vet. Rec. 119: 139.

15. Wyeth, P. J., Chettle, N., Gough, R. E., and Collins, M. S. 1987. Vet. Rec. 120: 286-287. 